Psychology of Language and Communication 2011, Vol. 15, No. 1

VERSITAOPEN

DOI: $10.2478 / \mathrm{v} 10057-011-0004-2$

\author{
ELWIRA BRYGOŁA \\ John Paul II Catholic University of Lublin
}

\title{
THE THREATENED IDENTITY: AN EMPIRICAL STUDY*
}

\begin{abstract}
This study explores the phenomenon of threatened identity that occurs because of significant, often abrupt changes in human life. As a result of a difficult experience, decision, change of cultural environment, loss of someone or something very important, an individual may feel he/she is someone different than before. Thus, establishing the continuity of one's personal identity may be a problem. In a report on this type of situation Glynis Breakwell (1986) proposes the term "threatened identity." She places it in the context of her structural model of identity. The present study is aimed at investigating possible images of threatened identity and characterizing them from the point of view of narrative sequences, the affective level and the ultimate - positive or negative - consequences of the individual's functioning. With regard to these aspects, five types of threatened identity have been distinguished from the empirical evidence: (1) the constructive re-evaluation, (2) the key experience, (3) the stable narrative sequence, (4) the seeking of power and autonomy and (5) the loss of part of oneself. Key words: identity, threat, continuity, changeability, narrative
\end{abstract}

One of the most important questions in human life - Who am I? - is a question about one's own identity. The contemporary world with its rapid changeability, its wide range of opportunities, its ways of self-realization and with the possibility of experiencing cultural differences, is a special context in an individual's life. Changeable social and cultural conditions often lead people to consider their own continuity in time, make them ask themselves whether they are still the same person as before. Sometimes changes are so significant that people have difficulty in finding a sense of their own continuity (see Gergen, 1991; Giddens, 1991; Hermans \& Dimaggio, 2007). The question about personal identity becomes a problem and there are situations when a threat to identity occurs.

Address for correspondence: Elwira Brygoła, John Paul II Catholic University of Lublin, Institute of Psychology, al. Racławickie 14, 20-950 Lublin, Poland. E-mail: elwira.brygola@kul.pl

* Paper prepared with the support of the Foundation for Polish Science. 


\section{The model of threatened identity and the question of identity change}

In describing Breakwell's (1986) model of threatened identity, three steps can be distinguished: (I) the structural components of identity in time, (II) the identity processes and the principles of their operation, (III) the threat to identity as a disturbance in ongoing identity processes. The structure of identity is conceived of as having two planes: the content and the value dimensions. The former comprises the defining properties of identity, the characteristics which the individual gives to describe himself/herself. These properties, taken together, mark the individual as a unique person, different in psychological profile from all others. Even when many components in the content dimension are shared with other people, their specific configuration is distinctive to the individual. The value dimension is the second axis of the structure of identity. Each element in the content dimension has a value attached to it. This value may be positive or negative and is attributable to the social beliefs interacting within one's previously established value system. It is worth noting that no component has a constant value. Attributed values are often subject to revision, depending on social circumstances. This means that the structure of identity is not a stable construction but continually undergoes changes. In the presented approach, identity is a dynamic set of processes which operate in a principled manner. There are two types of identity processes: assimilationaccommodation and evaluation. Although assimilation and accommodation are distinguishable, they are closely interdependent and as a result they are treated as one process. Assimilation concerns the absorption of new elements into the identity structure, accommodation refers to the adjustment of the existing structure in order to find a place for new elements. Similar notes are presented in the writings of Berzonsky $(1994,2003)$. According to him, when people live in a dynamic world of changing contextual demands, constructions that have been useful in the past may be invalidated by new turns of events. Hence, optimal identity development in the contemporary world involves an interplay between assimilative processes carried out by the existing structure of identity and accommodative processes that aim to modify this structure. Evaluation - the second process indicated by Breakwell (1986) - consists of allocating value to particular content and establishing subjective indices of worth for potential additions to identity. Assimilation-accommodation and evaluation interact and operate simultaneously to change both the content and the value dimensions of identity in an adaptive manner.

As mentioned above, identity processes are guided by principles. By assumption, the principles specify the end states which are desirable for identity. On the basis of the results of various studies (from introspective methods used by James to laboratory experimentation used by Gergen) Breakwell (1986) concludes that there are three prime principles: (1) distinctiveness of the person from other people, (2) continuity of the self across time and situations and (3) self-esteem as a feeling of personal worth or social value. Each of these principles makes some demands 
on the person. If all demands are compatible with one another, identity processes operate without obstruction. However, there can be a situation when demands made by the principles are contradictory and then a disturbance of the identity processes occur. Breakwell (1986) calls such situations threats to identity. From this perspective, threatened identity seems to be concerned with a conflict between different personal needs and also, as often happens, between personal needs and social expectations. A threat to identity entails a necessity to cope with it. Coping strategies may vary. Self-protection usually occurs at the intrapsychic level but can also include interpersonal or intergroup action. Depending on the manner of the reaction to the threat, the person may find an adaptive solution, or else the threatening situation will intensify and lead to a serious crisis of identity. In the study by Bosma and Kunnen (2001), the integrated model of identity development is considered to be a transaction between the person and the context. The transaction may result in a good match between existing commitments (considered according to Marcia's (1966) conception of identity statuses) and the context, or in confusion or conflict. The authors indicate that a matching situation confirms existing identity, whereas conflict is a trigger for identity change. Potentially, conflict may be a stimulus for identity development but can also bring about long-lasting diffusion (Kunnen, 2006). From Erikson (1968) onwards, the notion that conflicts often contribute to identity change is present in many studies and identity models (e.g. Adams \& Marshall, 1996; Kerpelman, Pittman \& Lamke, 1997; Roberts \& Rosenwald, 2001; Forthun, Montgomery \& Bell, 2006). As noted in several empirical investigations, there are some specific domains in which conflicts may occur. Cramer (2004) draws attention to internal psychological factors (e.g. personality, cognitive ability and current identity) and external life events as being capable of inducing identity change. Among life experiences related to identity change she points to those which belong to four areas: work, marital and family relationships, social network interaction and political orientation. In Cramer's (2004) study the influence of life events on identity remains in close association with internal defense mechanisms and level of intelligence. These results show that a change of identity is predicted not by life events as such but by them and personal traits. Although there have been attempts at specifying types of events that cause identity change (e.g. Kroger \& Haslett, 1991), other researchers (Berzonsky, 2003; Vleioras \& Bosma, 2005) indicate the role of personal interpretation of life experiences. They claim that the importance of the same type of events may be different for different people. This idea is also relevant to the context of threatened identity where the same type of events may have a different meaning for each person, may evoke different emotions and prompt different coping strategies. As a result the threat may bring about different, specific consequences in the individual's life.

Personal meanings of life events are especially emphasized in narrative psychology. One of the main representatives of this approach, Dan McAdams (1989, 1996, 2001) formulates the theory of narrative identity. The framework of his theory is 
that successive stages in identity development are compared to the creation of a personal myth and many elements (such as narrative tone, imagery, theme, ideological setting, imago) make the story of one's life coherent. In this way, the individual gains a sense of unity and purpose. However, some questions appear when we think about significant changes, difficult experiences and other threatening circumstances. What happens when a threatening situation occurs and how then do the individuals maintain coherence and continuity of their own story, their own identity? Are personal meanings stable or fluid? Hubert Hermans (1989, 2000; Hermans \& Kempen, 1993; Hermans \& Hermans-Jansen, 1995; Hermans \& Hermans-Konopka, 2010) suggests that the self has a dynamic character. He terms the self as an organized process of valuation and emphasizes the possibility of movement within the system of personal meanings. This approach takes into account changes over time in the context the individual lives in, various points of view that he/she may have about the same events and valuation and re-evaluation of them in the light of new experiences. In Hermans' valuation theory (Hermans \& Hermans-Jansen, 1995) the emotions and feelings which accompany life events have a particular significance. According to this theory, emotions and feelings form the affective level of the self that in turn constitutes the manifest level of this system. The manifest level is the reflection of functioning of two basic motives: the $S$ motive (i.e. self-maintenance and self-expansion) and the $\mathrm{O}$ motive (i.e. contact and union with other people or environment), which are located at the latent level and manifest themselves in affect. Access to the basic motives is possible by formulation of valuations and their affective assessment. On this basis, Hermans constructed the Self-Confrontation Method which provides valuable material for psychotherapeutic work but also for research analyses. With regard to the aim of present study, the application of the Self-Confrontation Method was used in the survey. This enabled a qualitative analysis of narratives and an analysis of the affective level of personal meanings which illustrate the threatened identity.

\section{The problem}

The study has an exploratory character. It is based both on qualitative analysis (narratives and valuations) and quantitative data (affective indices). The main problem of the research project is: Does the threatened identity have different versions, and if it has, what are these versions? The current exploration of threatened identity focuses on possible forms of its course and consequences that follow as a result of the threat experience.

Besides the general question, five detailed questions are put forward:

Question 1: What narrative sequences illustrate the threatened identity?

Question 2: What affective patterns accompany the threatened identity?

Question 3: How does the affective climate change in situations before and after the experience of the threat to identity? 
Question 4: What personal meanings are given to the experience of the threat to identity?

Question 5: What are the dynamics of self-enhancement (the S motive) and contact with the other (the $\mathrm{O}$ motive) in narratives regarding the threatened identity?

\section{Participants and method}

This study follows an idiographic approach. The research group consisted of 14 participants - university students from European countries. The participants included 8 women (a Belgian, a Belarusian, a Czech, a Dane, 3 Poles and a Slovene) and 6 men (a Belgian, a Frenchman, a Hungarian, a Pole and 2 Ukrainians). The age of the respondents ranged from 22 to $26(M=23.64 ; S D=1.34)$. The selection for the sample was done with regard to established inclusion criteria. According to these, (1) the pre-investigation interview suggested that there had been crucial experiences in the person's life that had brought important changes in functioning and in a sense of personal identity, (2) the way of the person's self-presentation suggested that they were willing to think deeply about their life and to tell their own story.

\section{Instrument}

The Self-Confrontation Method by Hermans (Hermans \& Hermans-Jansen, 1995) is an idiographic instrument based on the valuation theory. The method is designed for inquiry into the relationship between valuations and types of affect. The generation of valuations is followed by an affective assessment which is performed by means of a list of affect-denoting terms. As a result, affective patterns for each valuation and the sequence of affective patterns for the whole system of valuations are obtained. Each affective pattern refers to the latent motives (the $\mathrm{S}$ motive and the $\mathrm{O}$ motive) associated with a particular valuation. Numerous indices provide information about the expression of the basic motives in a single valuation and in the valuation system as a whole. If both basic motives are fulfilled $(+\mathrm{HH})$ or one of them is fulfilled $(+\mathrm{S}$ or $+\mathrm{O})$, the positive affect prevails over the negative one $(\mathrm{P}>\mathrm{N})$. When there are some obstacles and both motives are frustrated (-LL) or one of them is frustrated $(-\mathrm{S}$ or $-\mathrm{O})$, then the negative affect prevails over the positive one $(\mathrm{N}>\mathrm{P})$. It can also be the case that some valuations are connected with ambivalent affect, without a clear difference between the positive and the negative affect $(|\mathrm{P}-\mathrm{N}|<10)$.

In the standard version of the Self-Confrontation Method, there is a set of questions which encourage the person to tell their own story, concentrating on especially important events from the past, present significant experiences and also anticipated events and plans for the future. However, Hermans (Hermans \& Hermans-Jansen, 1995) points to the possibility of adapting the method to specific research purposes. 
As regards the present study, special questions have been designed, together with a short introduction to the research topic (see Appendix).

\section{Procedure}

The survey was carried out in Belgium and Poland. After taking into account the inclusion criteria and asking for participation in the survey, 14 students were included in the sample. The participants were students from Europe studying at the Catholic University of Leuven (Belgium) or the Catholic University of Lublin (Poland), either as native students or as scholarship holders within the Erasmus Program.

The survey was individual in character. Each person received a set of questions and then began recounting a narrative. All the participants gave personal meanings for recounted events, decisions, circumstances and on this basis formulated valuations. Next, they were asked to assess the valuations within a matrix of 24 affect terms. Concentrating on a single valuation, the participants indicated on a six-graded scale (from 0 to 5) to what extent they experienced each affect in relation to the particular valuation. After an assessment of all the valuations, each person had the task of marking on the same matrix how he/she felt during the past few days and how he/she would have liked to feel. In this way, two indices were obtained: the index of general affect and the index of ideal affect. In compilation with other gathered data, these indices were significant in further analyses and interpretations.

The affective pattern of each valuation includes four indices: S, O, P and $\mathrm{N}$. Index $\mathrm{S}$ is the sum score of four affects concerned with the self-enhancement motive (self-esteem, strength, self-confidence and pride). Index $\mathrm{O}$ is the sum score of four affects referring to the contact with other motive (care, love, tenderness and intimacy). Index $\mathrm{P}$ is the sum score of eight general positive affects (joy, satisfaction, enjoyment, trust, safety, energy, inner calm and freedom). Index $\mathrm{N}$ is in turn the sum score of eight general negative affects (powerlessness, anxiety, shame, self-alienation, guilt, loneliness, inferiority and anger). The scores for the $\mathrm{S}$ and $\mathrm{O}$ indices range from 0 to 20 . The scores for the $\mathrm{P}$ and $\mathrm{N}$ indices range from 0 to 40 .

A computer program was used to obtain the S, O, P, N indices and other statistical information (e.g. the correlation between particular valuations and between valuations and the general or ideal affect). The obtained systems of valuations with their affective characterization were placed in separate tables for each participant. Only representative cases will be shown and discussed in the presentation of the results.

\section{Results}

An analysis of the cases revealed various pictures of threatened identity. On the basis of the gathered empirical material, five types of the studied phenomenon were differentiated. This was done with regard to two main criteria: first - content, 
and second - affective patterns present within the constructed valuation systems. The description of each type of picture will be based on the domination of one of these criteria and will be shown by means of the most interesting, representative case studies.

\section{The constructive re-evaluation}

A common feature of pictures that have been termed constructive re-evaluation is the gradual movement from some ordeal, crisis situation to an emotionally and mentally positive state. A difficult experience, although evoking painful feelings, does not make the person immerse himself/herself in hopelessness and distress. Constructive passage is visible not only in the narrative sequences but also in the affective profiles of created valuation systems.

Anton $^{1}$ is 25 years old, he comes from Ukraine, from a small village near Chernobyl where the explosion in the nuclear power plant took place in 1986, when he was 5 . Anton began his narration and valuation system (see Table 1$)^{2}$ from a recollection of this event. The nuclear catastrophe irretrievably changed his "sunny," as he describes it, childhood and affected his further story. As a result of the obligatory evacuation of local inhabitants, Anton's family moved to Lviv. Their financial situation rapidly became worse. His parents lost their jobs, more and more conflicts occurred between them. His father started to abuse alcohol and to become violent toward his wife and children. Anton formulated the valuation (No. 3):

The view of my father hitting my mother paralyzed me,

\begin{tabular}{llll}
$\mathrm{S}$ & $\mathrm{O}$ & $\mathrm{P}$ & $\mathrm{N}$ \\
\hline 0 & 0 & 0 & 33
\end{tabular}
made me defenseless and helpless.

The affective climate of the cited valuation indicates the lowest point in Anton's system of valuations (correlation with ideal affect $r=-0.84$ ). McAdams (2001) calls such a point in the life story as the nadir experience, which is associated with the most negative feelings. Experience of the loss of safety and warmth at home caused an escape from the threatening and hostile reality. Anton decided to go to the United States. His two-year stay in such a faraway and unfamiliar country did not bring the expected changes but intensified his previous feeling of being lost and lonely. Although the affective climate of valuations concerning his stay in America indicates experiences of helplessness and isolation (-LL), the presence of positive affect and the trace of occurrence of basic motives suggests that some minimal gratification was achieved and this was no longer total defeat. Perhaps Anton experienced some positive feelings because of his separation from difficult and painful situations in his family and in his homeland. It also seems possible that the presence of these feelings is partly an effect of re-evaluation of experiences that

All names used in the paper have been changed.

2 Tables containing whole valuation systems are provided in the Appendix. 
were negative but now, from a developmental perspective, are seen as somehow positive and needed. Although the stay in the United States provided a physical distance from the familial crisis, which could bring some kind of satisfaction, Anton felt he did not belong to that world. He also understood that escaping from home did not solve his problems. The wish to return to Ukraine was stronger and stronger but simultaneously Anton was afraid of his independence. The suggestion that he go to Poland to study in Lublin turned out to be the solution to Anton's inner conflict. For him it was a very important point. He talks about it in the valuation (No. 7):

Coming to Lublin to study was an ideal solution.

\begin{tabular}{llll}
$\mathrm{S}$ & $\mathrm{O}$ & $\mathrm{P}$ & $\mathrm{N}$ \\
\hline 12 & 13 & 31 & 20
\end{tabular}
I did not lose my independence, at the same time I was near home.

Although the negative affect is present in the cited valuation (which can be an echo of previous valuations), the increase of affect manifesting the basic motives and the intensification of positive affect are visible. The affective pattern of this valuation reflects the experience of power and union $(+\mathrm{HH})$.

Anton's arrival in Lublin opened a new stage in his life, allowed him to confront many problems which had previously made full self-acceptance and close relationships with other people impossible. Still considering many existential questions, Anton experienced a religious crisis that intensified the search for his own identity. Meeting friendly people helped Anton to recognize the truth about himself and to accept values which he now wants to realize. Past experiences led Anton to a change in attitude toward himself and toward the world. His valuation system concludes with two valuations (Nos. 12 and 13) which show a very high level of positive affect and also of affect concerned with both basic motives. These valuations and general affect have a high correlation with ideal affect (respectively $r_{12}=0.82, r_{13}=0.84, r_{\text {gen. }}=0.88$ ) which indicates a positive affective climate ending the narrative and characterizing Anton's current state.

The presented case is an example of constructive re-evaluation. In the telling of one's life story, McAdams (2001, McAdams \& Bowman, 2001) calls the gradual movement from emotionally negative stages to a positive outcome a redemption sequence and shows that this kind of sequence can be used to convey a progressive understanding of the self. The self appears here as growing, moving forward, making progress over time. McAdams (2006) even proposes the term the redemptive self. Tomkins (1987) described a similar process by means of the notion of the limitation-remediation script. This kind of script begins with a negative-affect situation, when the person suffers in some way. With time, the individual overcomes the suffering, improves the problem situation and moves forward to a positive-affect state. In relation to this type of experience Janoff-Bulman wrote: "By engaging in interpretations and evaluations that focus on the benefits and lessons learned, survivors emphasize benevolence over malevolence, meaningfulness over random- 
ness, and self-worth over self-abatement" (Janoff-Bulman, 1992, cited in McAdams \& Bowman, 2001, p. 26).

It is worth noting that making an effort to overcome a difficult situation is concerned with ambivalent affect. Perhaps this is the point when conflict between identity principles is given voice. The continuity principle is against gaining acceptance for change, similarly to self-verification (see Swann, 1987), the self-esteem principle dictates improvement in one's own functioning, analogous with the selfserving bias (see Duval \& Silvia, 2002). Additionally, the distinctiveness principle is present and may suggest staying in the former style of being and action (when the style is highly individualized and lets the person have a sense of uniqueness) or may induce change in order to differ from others (when the individual merges with other people, taking part in uncritically popularized beliefs and lifestyle). The conflict situation caused by inconsistent demands of identity principles is threatening to identity. Those participants who presented the constructive re-evaluation went from this threatening point to a more favorable way of personal development.

\section{The key experience}

The picture of the key experience includes stories in which there is a turning point that changes the direction of the narrative. The main experience brings a break in motivation in the undertaken action, in the perception of the world and other people and, most importantly, the self-concept is also changed. At the affective level, this transformation is noticeable in a clearly different emotional climate coupled with the key event and in further changes of feelings - positive and negative and associated with the basic motives as well.

Katrien is 24 and comes from Belgium. She spent her childhood in a happy family. Her life had not considerably differed from her peers' lives by the time she began pedagogical studies at university, near her hometown. During her studies she thought about doing volunteer work in some poor country. She finally made a decision and went to Guatemala for a year. As she says (see Table 2), it was her first really independent choice. Shortly after arriving in Guatemala, Katrien felt acute fear and helplessness toward the people who were suffering from poverty. She talks about these experiences in the valuations (Nos. 3 and 4):

The world of poverty and starvation scared me.

\begin{tabular}{llll}
$\mathrm{S}$ & $\mathrm{O}$ & $\mathrm{P}$ & $\mathrm{N}$ \\
\hline 1 & 4 & 0 & 22 \\
$\mathrm{~S}$ & $\mathrm{O}$ & $\mathrm{P}$ & $\mathrm{N}$ \\
\hline 0 & 13 & 1 & 27
\end{tabular}

When people were dying in front of my eyes I felt totally helpless.

The reality of privation evoked many difficult feelings previously alien to Katrien. Helping needy people, formerly present only as an idea, now became available as a direct experience. It was precisely this moment which turned out to be the key experience. During her stay in Guatemala, Katrien overcame her fear and feeling 
of helplessness. With time, the negative affect was replaced by positive feelings connected with noticing the good she was doing. Katrien started to look at human life differently. The following valuation (No. 5) shows this meaning:

\section{Every human life started to have a huge and unique value for me.

\begin{tabular}{llll}
$\mathrm{S}$ & $\mathrm{O}$ & $\mathrm{P}$ & $\mathrm{N}$ \\
\hline 12 & 15 & 22 & 6
\end{tabular}

The affective climate of the cited valuation reflects the fulfillment of both basic motives $(+\mathrm{HH})$ and differs markedly from the climate of previous valuations (-LL and -O). Such a clear change suggests the occurrence of a turning point in Katrien's narrative and valuation system. From this point, positive affect dominates and, it is worth noting, the feelings concerned with the $\mathrm{O}$ motive increase. The dynamics of the $S$ motive is also significant. In almost the whole valuation system, the $S$ motive is satisfied, except valuations relating to the experience of the first contact with the other world. For Katrien, who has lived in Western Europe with all the standards that are characteristic of this part of the world, arriving in a foreign environment swayed not only her sense of power and self-confidence but also her sense of her own identity. Her stay and volunteer work in Guatemala affected Katrien's selfperception and her next undertaken action. As she says, it was a turning point in her life. Returning to Belgium gave her the feeling that part of herself had been left in Guatemala. But for her it is not the loss that she regrets, rather the benefit of self-spreading and broadening her outlook on the world.

As a result of the occurrence of the turning point in the valuation system, the affect and the motivation change. The key experience may be treated as a threat to identity because it brings about a change that may not be accepted by the continuity principle.

The key experience is closely associated with the turning point in the life story (McAdams, 2001). The thematic area of this kind of experience is very extensive. In an individual's life the turning point is a subjectively important event which brings about a significant change of self-understanding, a change in one's own motivation and often a change in relationships with other people. In the narrative approach many surveys on personal meanings of turning points have been conducted (e.g. McAdams, Josselson \& Lieblich, 2001). It is worth taking a look at the exploration of social movement and the formation of personal identity among first-generation college students (Ochberg \& Comeau, 2001; Roberts \& Rosenwald, 2001). Young people from a lower social class who decide to obtain a higher education leave their home surroundings. The consequences of this choice affect their relationships with their parents, siblings and friends who have stayed behind. It is supposed that among first-generation college students the course of identity processes encounters serious impediments, concerned with a breach in identification with one's community of origin and with being admitted into a new social environment. For those who despite the tension between their old and new world manage to reach rewarding 
integration and become well-developed personally, the decision about changing their social status gains the importance of the key experience.

\section{The stable narrative sequence}

The stable narrative sequence shows a picture of threatened identity in which the maintenance of the stable affective pattern is the most specific feature. The narrative is focused on experiences that barely create a varied story, and even if some valuations have other content, their emotional climate remains almost constant.

Marta is a 22-year-old Psychology and Family Science student who comes from Poland. She speaks warmly about her parents and brothers, with a feeling of closeness toward them. Marta's childhood was calm. Problems, if they occurred, were not revealed. Everyone had to agree that things were fine and this order had to be preserved. Marta could feel joy and power but she was not allowed to feel anger, to be fearful and weak. Living for years in a family that accepted only good news and did not take note of bad feelings, Marta did not learn to admit to difficulties, failures and sadness. When she began to ask herself who she was and what she needed, she realized her own inability to answer these questions. Marta felt that she was inaccessible to herself. A new stage in her life came when she became a student of Psychological Studies. This was a time for confronting herself and other people who perceived her differently than she saw herself. This period brought many changes in her way of thinking about herself and her family. She formulated many detailed valuations on these changes (see Table 3). But, although difficult experiences occurred at the content level, there is no reflection of them at the affective level. Marta's valuation system is opened by a very positive affective climate that sets the emotional tone for the whole. Even if the content of valuations (No. 3 and 4) suggests difficult feelings, the affect which characterizes them is only ambivalent. The lowest point of Marta's narrative is contained in the valuation (No. 5):

My friend started to turn away from me-

\begin{tabular}{llll}
$\mathrm{S}$ & $\mathrm{O}$ & $\mathrm{P}$ & $\mathrm{N}$ \\
\hline 1 & 6 & 3 & 10
\end{tabular}
I felt that I had lost her support and that of my parents who I had always trusted, and my own.

The negative affect here is the highest in the whole valuation system. In all the next valuations, Marta excludes any negative feelings, concentrating solely on positive changes. It is worth noting that in the whole filled matrix of affect there are no feelings like anxiety, shame and sense of inferiority, while on the relatively stable, high level there are feelings like joy, sense of security and calmness. As a result of such an affective assessment, Marta's valuation system appears as rigid, devoid of flexibility in moving from one type of experience to another. In view of this analysis there is the probability of occurrence of dissociation, mainly in the suppression form. According to Hermans (Hermans \& Hermans-Jansen, 1995) this 
kind of dissociation concerns the relation between the content of valuation and its affective component. Suppression is visible when the individual formulates some valuations and strongly diminishes feelings associated with their content. Marta's concentration on the positive aspects of various situations is so huge that she has moved away from negative affect. However, in some circumstances the occurrence of negative feelings is a sign of a well-functioning self. The rigidity of Marta's valuation system is probably an effect of her inflexible upbringing at home. Although at the verbal level Marta notices the consequences of principles that ruled in her family, the emotional climate of her valuation system is characterized by relative stability. At the affective level there are no significant changes, no turning points that would modify her feelings and direct her motivation. Marta's narrative is focused on strengthening the effects of experiences she has gone through. Simultaneously, the account of events directly related to changes is omitted or reduced. This makes the valuation system display the stable narrative sequence which could be a means of defense against a threat to identity.

The rigidity of the valuation system may also show a contrasting picture and display strong concentration on negative feelings, which is connected with a reduction in the positive affect and affect manifesting the basic motives. This kind of stable narrative sequence is seen in Jana's case (see Table 4). All her valuations reveal frustration of both the $\mathrm{S}$ motive and the $\mathrm{O}$ motive (-LL). The affective patterns of all valuations are similar to each other and to general affect (the correlation between particular valuations and general affect is in the range from $r=0.67$ to $r$ $=0.91$ ). The above observation suggests that in this case dissociation also occurred. Experiences which would disturb the system's homogeneity (even if the system is focused on negative feelings) are omitted.

Both Jana's and Marta's valuation systems present the stable narrative sequence as one version of the threatened identity. The tendency to maintain a similar affective climate in the course of narrative and in assessment of valuations is the most specific feature of these pictures. With reference to McAdams' $(1989,1996)$ narrative identity theory, suppression of some kinds of feelings and emotional rigidity may be the result of a narrative tone formed in early childhood. The narrative tone may be optimistic or pessimistic and as such decides about the emotional climate of the created life story. A high-intensity narrative tone may cause dysfunctions of the self system, make it rigid and incapable of coping with the threat in an adaptive manner.

\section{The seeking of power and autonomy}

Narratives and valuation systems where the self-enhancement motive dominates have been described as the seeking of power and autonomy. The main tendency in this type of threatened identity is the acquisition of independence, power and, as a result, the building of self-esteem. With respect to the identity problem, the effort to attain power seems to be a way of coping with the threat (see Batory, 2010). The results of using this strategy may be various. It may lead to positive personal 
development but sometimes it is a consequence of egocentric traits and brings only superficial strength for the self.

Gergo is 26 years old. He comes from Hungary, from an affluent family. His parents provided him not only with financial prosperity but also high social status. Gergo starts his valuation system (see Table 5) with a negative emotional climate concerned with the frustration of the self-enhancement motive. He talks about a feeling of weakness in the face of expectations that his family and neighbors have toward him. Many social expectations have blocked the demonstration of his aspirations and limited his development toward independence. As a result of strong attachment, the border between Gergo and his parents was obliterated. In these conditions the formation of personal identity encountered serious obstacles. Gergo felt he had to fight for himself, for the ability to direct his own life. However, his attempts at defiance have not brought satisfactory effects for a long time. The frustration of the self-enhancement motive on the one hand has intensified Gergo's striving for autonomy, whilst on the other it has led to discouragement from action to obtain independence. The question about his own identity has not found an answer since Gergo has not decided to take steps to separate from his parents. The decision to go on a scholarship to Belgium gave him the chance to live in new conditions, according to rules set by himself. It gave Gergo the opportunity to get to know himself, to perceive his own value but also to allow himself to be weak. As a result, Gergo's sense of power and personal autonomy has increased. In his narrative the sense of autonomy is the aim that marks out the direction of undertaken action. Although in the first part of the valuation system the $\mathrm{S}$ motive is frustrated, in the whole story the seeking of autonomy becomes the main issue and the narrated events revolve around it. At the end of his narrative Gergo expresses fear as to whether he will manage to maintain his independence after coming home. But he is sure he will not give up and talks about this in the last valuation (No. 11):

I know I will fight for myself, my life, my freedom.

\begin{tabular}{llll}
$\mathrm{S}$ & $\mathrm{O}$ & $\mathrm{P}$ & $\mathrm{N}$ \\
\hline 20 & 3 & 19 & 5
\end{tabular}

The affective patterns of the last valuations, general affect and ideal affect show the experience of positive self-enhancement $(+S)$. At the same time it is worth noting that there is a low level of feelings reflecting the $\mathrm{O}$ motive in the whole system. The seeking of power and autonomy dominates the content of Gergo's narrative and marks the direction of his motivation.

Attempts at finding one's own power and value are usually the result of natural need and have developmental significance (Kernis, 2003, 2005). However, there are also cases where the search for self-enhancement turns out to be an egocentric defense against situations that threaten a person's self-esteem. Then, the individual is focused on their own self. Relationships with other people serve only to build 
a positive self-image (Foster, Kernis \& Goldman, 2007; Kernis, Lakey \& Heppner, 2008). In this way, personal identity is protected against risky changes.

In the context of threatened identity, Breakwell (1986) points to the significance of a sense of control over life changes. It happens that the ability or possibility of controlling events, sometimes also one's own action, is limited either for internal or external reasons. Then, the individual loses self-efficacy and as a result, changes in self-perception may occur. These changes may disturb the continuity of personal identity, hence the lack of control over changes is one of the most specific features of the threat situation. The mechanism is that the lack of control leads to a sense of weakness which in turn causes a decrease in self-esteem (see DeMello \& Imms, 1999). The person, coping with the threat, seeks power and autonomy and in this way focuses on actions which strengthen their own self.

\section{The loss of part of oneself}

The situation of a threat to identity may concern various aspects of the individual's functioning. It may be related to existential issues (the meaning of life, the system of values), changes of environment (in a social and cultural context), the bodily sphere (physical abilities, appearance) or the material domain (properties). A threat to identity may also occur in the context of close relationships with other people who are perceived as significant. The bonds with significant others constitute personal identities for each of them. It is possible for a conflict situation to occur in any of the above-mentioned domains, bringing about the loss of important value. Many years ago William James (1890) distinguished between the self as a subject $(I)$ and the self as an object $(\mathrm{Me})$ that contains spiritual, material, social and bodily elements. Both these aspects of the self create the whole, forming a sense of one's own identity (see Epstein, 1991). The importance given to particular aspects of the self decides that their loss causes the loss of part of oneself.

Julie is 24 years old. She was born in Denmark and she spent her childhood there. Her mother comes from Portugal, her father is Danish As Julie talks about herself (see Table 6), two contrasting temperaments - southern and northern - are mixed in her. Since her earliest years, she has experienced a desire to express herself through literature and has sought meaning in life. At the same time, she has felt that she was not like other, ordinary people and was full of doubts whether it was better to live like other people or to live her own way. This inner conflict was supported by the attitude of Julie's father who represented "a world without depth." Julie's father has not understood her desires, has not tried to enter his daughter's world. This mutual incomprehension increased over time. Julie has been writing more and more. She has found an outlet for her feelings and quests in poetry. She has found herself there, rooted in a world of creativity that has given her a chance for self-realization. Writing has become her passion. Julie's dream was clear - Literature Studies in Copenhagen. She knew she wanted this but her father wanted 
something different for her. He expected her to follow in his footsteps and take over the family business. For Julie, her father's plan for her life was impossible to accept. Julie faced the choice between realizing her own desires and meeting her father's expectations. She knew that her father would not approve of her decision regarding the humanities and writing. According to him, it would be an unpractical way of earning a living. However, Julie felt that she could not act against her nature and that writing and literature was her way. She followed this route. Her father's disapproval of her decision caused doubts to arise in her mind for some time. Julie knew that if she stuck with her choice, she would lose her father. Finally, she enrolled in her chosen studies. The time in Copenhagen was difficult for her but she did not withdraw from her choice. Julie feels she has lost her father, although she hopes this is not the end. She still has not reconciled herself to the loss, which she talks about in the valuation (No. 17):

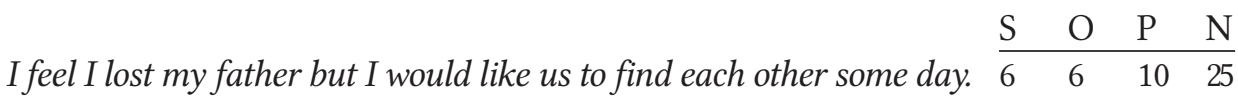

The affective climate of the above valuation is characterized by a prevailing negative affect over the positive one. The content is associated with a low level of expression of both basic motives, which points to the experience of helplessness and isolation (-LL). This moment reflects an important loss which entails deep sorrow and may also evoke anger. The latter is seen in the next valuation (No. 18):

Thomas Mann said: 'Literature is not a profession, it is a curse... \begin{tabular}{llllll}
\hline & S & $\mathrm{O}$ & $\mathrm{P}$ & $\mathrm{N}$ \\
\cline { 2 - 4 } & 2 & 10 & 21
\end{tabular} This is the truth.

In Julie's story, the two different paths were impossible to combine. The choice of either of them meant giving up something personally important. Julie's decision brought a loss that has evoked difficult feelings till now. Interestingly, although the emotional climate of Julie's narrative renders a sense of loss, the affective patterns of the last valuations do not convey frustration of the $\mathrm{O}$ motive $(-\mathrm{O})$ but the experience of helplessness (-LL) and anger (-S). Maybe it is just the moment which reflects not so much the loss of another person as the loss of part of oneself.

An important loss is usually threatening to identity. Processes guided by the continuity principle, and often also by the self-esteem principle, are disturbed. However, the individual does not always feel the loss of part of their own identity. A sense of the loss of self might occur, but adaptive strategies of coping with a threat make the person find a new content for personal identity. For instance, this kind of experience may happen after the constructive passing of grief (Neimeyer, 2001, 2005, 2006; Worden, 2009). As a result, further development of the self is enabled. 


\section{Conclusion}

In the face of diverse events, experiences, an individual's feelings and points of view, the question about the coherence of personal identity arises. According to McAdams $(1989,1996,2001)$, individuals aim to create a coherent life story. However, there is doubt as to how a person looks at their own life from the perspective of very difficult experiences and important changes which have caused a threat to identity. The results of the present study show that the coherence of narrative and by the same token the coherence of identity is not always retained. Threatening experiences often change the course of a life story, challenge previously held values, change the motivation and modify the self-image. Moreover, there is also the possibility of co-occurrence of mutually opposite meanings given to events and life experiences. The adaptively functioning individual is able to include these opposite meanings in an organized system of self. This idea is close to Hermans' (Hermans \& Kempen, 1993) theory of the dialogical self. According to this idea, the diversity of looking at one's own life - at events, decisions, actions - is called the multiplicity of I-positions. Each I-position has its own voice and may tell its own story. The person may look at their own life from many perspectives and as a result may have many sub-identities (see Hofman, 1983, referred to in Breakwell, 1986; about the plurality of the self see also Rowan \& Cooper, 1999). In the context of threatened identity the assumption about the self system as a polyphonic structure suggests the possibility of occurrence of several identities which do not necessarily threaten one another. Moreover, they can come into the inner discourse and negotiate the optimal point of view and adaptive manner of action (see Hermans \& Dimaggio, 2007; Stemplewska-Zakowicz et al., 2005; Pollard, 2008). A problem arises when the individual faces a dilemma. The various points of view prompt different solutions, and then choosing one means rejecting another. In turn, this may cause a feeling of important loss (as in Julie's case). However, as P. Oleś (2008) notes, sometimes very few strongly internalized attributes are enough - despite the loss of almost everything - to maintain a sense of personal identity. But the loss of these attributes - even if there are not a lot of them - is sometimes enough for the individual to be confronted with the necessity of rebuilding their own identity.

The results of many surveys (e.g. Raggatt, 2000; Ligorio \& Pugliese, 2004; Van Halen \& Janssen, 2004) confirm the assumption about the multivoiced self. However, some questions still arise. How is it possible to establish an identity when extremely different voices of I-positions are present? To what extent can the continuity of identity be retained in difficult experiences which bring about significant life changes, when different I-positions assess them differently? What are the identity changes after the suppression of some voices which would limit the realization of foreground personal aspirations? Is the suppression of the voice of an important I-position possible by and large, and how does the individual manage to solve the inner conflict caused by various self voices? 
The threat to identity, understood as a situation of discord between contrasting demands of identity principles, seems to be a conflict of I-positions that suggest various aims. Under these kind of conditions, how can the individual effectively and adaptively cope with the threat? Which I-position is the most important and what happens to the rest? How does the identity protect itself against disintegration in such a way that the identity is retained as the "core" of the person during their whole life span? The above questions are some proposals for further research on the identity problem - changes of identity, protection of the sense of continuity, the influence of difficult situations and decision processes on identity, and also ways of adaptive coping with threatening conditions.

\section{References}

Adams, G.R. \& Marshall, S.K. (1996). A developmental social psychology of identity: Understanding the person-in-context. Fournal of Adolescence, 19, 429-442.

Batory, A.M. (2010). Dialogicality and the construction of identity. International fournal for Dialogical Science, 4, 45-66.

Berzonsky, M.D. (1994). Self-identity: The relationship between process and content. Journal of Research in Personality, 28, 453-460.

Berzonsky, M.D. (2003). The structure of identity: Commentary on Jane Kroger's view of identity status transition. Identity: An International fournal of Theory and Research, 3, 231-245.

Bosma, H.A. \& Kunnen, E.S. (2001). Determinants and mechanisms in identity development: A review and synthesis. Developmental Review, 21, 39-66.

Breakwell, G.M. (1986). Coping with threatened identities. London: Methuen.

Cramer, P. (2004). Identity change in adulthood: The contribution of defense mechanisms and life experiences. Fournal of Research in Personality, 38, 280-316.

DeMello, L.R. \& Imms, T. (1999). Self-esteem, locus of control and coping styles and their relationship to school attitudes of adolescents. Psychological Studies, 44, 24-34.

Duval, T.S. \& Silvia P.J. (2002). Self-awareness, probability of improvement, and the self-serving bias. Fournal of Personality and Social Psychology, 82, 49-61.

Epstein, S. (1991). Cognitive-experiential self-theory: An integrative theory of personality. In R. Curtis (Ed.), The relational self: Theoretical convergences in psychoanalysis and social psychology (pp. 111-137). New York: Guilford Press.

Erikson, E.H. (1968). Identity, youth and crisis. New York: Norton.

Forthun, L.F., Montgomery, M. J., \& Bell, N. J. (2006). Identity formation in a relational context: A person-centered analysis of troubled youth. Identity: An International fournal of Theory and Research, 6, 141-167.

Foster, J.D., Kernis, M.H., \& Goldman, B.M. (2007). Linking adult attachment to self-esteem stability. Self and Identity, 6, 64-73.

Gergen, K. (1991) The saturated self: Dilemmas of identity in contemporary life. New York: Basic Books. 
Giddens, A. (1991). Modernity and self-identity. Self and society in the late modern age. Cambridge: Polity Press.

Hermans, H.J.M. (1989). The meaning of life as an organized process. Psychotherapy, 26, 11-22.

Hermans, H.J.M. (2000). Meaning as movement: The relativity of the mind. In G.T. Recker \& K. Chamberlain (Eds.), Exploring existential meaning (pp. 23-38). Thousand Oaks: Sage.

Hermans, H.J.M. \& Dimaggio, G. (2007). Self, identity, and globalization in times of uncertainty: A dialogical analysis. Review of General Psychology, 11, 31-61.

Hermans, H.J.M. \& Hermans-Jansen, E. (1995). Self-narratives: The construction of meaning in psychotherapy. New York: Guilford Press.

Hermans, H.J.M. \& Hermans-Konopka, A. (2010). Dialogical self theory: Positioning and counter-positioning in a globalizing society. Cambridge: Cambridge University Press.

Hermans, H.J.M., \& Kempen H.J.G. (1993). The dialogical self: Meaning as movement. San Diego, CA: Academic Press.

James, W. (1890). The principles of psychology (Vol. 1). London: Macmillan.

Kernis, M.H. (2003). Toward a conceptualization of optimal self-esteem. Psychological Inquiry, 14, 1-26.

Kernis, M.H. (2005). Measuring self-esteem in context: The importance of stability of self-esteem in psychological functioning. Fournal of Personality, 73 (6), 1569-1605.

Kernis, M.H., Lakey, Ch.E., \& Heppner, W.L. (2008). Secure versus fragile high selfesteem as a predictor of verbal defensiveness: Converging findings across three different markers. Journal of Personality, 76 (3), 477-512.

Kerpelman, J.L., Pittman, J.F., \& Lamke, L.K. (1997). Toward a microprocess perspective on adolescent identity development: An identity control theory approach. Journal of Adolescent Research, 12, 325-346.

Kroger, J. \& Haslett, S.J. (1991). A comparison of ego identity status transition pathways and change rates across five identity domains. International fournal of Aging and Human Development, 32, 303-330.

Kunnen, E.S. (2006). Are conflicts the motor in identity change? Identity: An International Journal of Theory and Research, 6, 169-186.

Ligorio, M.B. \& Pugliese, A.C. (2004). Self-positioning in a text-based virtual environment. Identity: An International fournal of Theory and Research, 4, 337-353.

Marcia, J.E. (1966). Development and validation of ego-identity status. fournal of Personality and Social Psychology, 3, 551-558.

McAdams, D.P. (1989). The development of a narrative identity. In D.M. Buss, \& N. Cantor (Eds.), Personality Psychology (pp. 160-174). New York: Springer Verlag.

McAdams, D.P. (1996). Narrating the self in adulthood. In J. E. Birren, G. M. Kenyon, J.E. Ruth, J.J.F. Schroots, \& T. Svensson (Eds.), Aging and biography. Explorations in adult development (pp. 131-148). New York: Springer Publishing. 
McAdams, D.P. (2001). The person: An integrated introduction to personality psychology (3rd ed.). Forth Worth: Hartcourt Brace College Publishers.

McAdams, D.P. (2006). The redemptive self: Stories Americans live by. New York: Oxford University Press.

McAdams, D.P. \& Bowman, P.J. (2001). Narrating life's turning points: Redemption and contamination. In D.P. McAdams, R. Josselson, \& A. Lieblich (Eds.), Turns in the road: Narrative studies of lives in transition (pp. 3-34). Washington, DC: American Psychological Association.

McAdams, D.P., Josselson R., \& Lieblich A. (Eds.) (2001). Turns in the road: Narrative studies of lives in transition. Washington, DC: American Psychological Association.

Neimeyer, R.A. (Ed.) (2001). Meaning reconstruction and the experience of loss. Washington, DC: American Psychological Association.

Neimeyer, R.A. (2005). Grief, loss, and the quest for meaning: Narrative contributions to bereavement care. Bereavement Care, 24, 27-30.

Neimeyer, R.A. (2006). Bereavement and the quest for meaning: Rewriting stories of loss and grief. Hellenic Journal of Psychology, 3, 181-188.

Ochberg, R.L. \& Comeau, W. (2001). Moving up and the problem of explaining an "unreasonable" ambition. In D. P. McAdams, R. Josselson, \& A. Lieblich (Eds.), Turns in the road: Narrative studies of lives in transition (pp. 121-149). Washington, DC: American Psychological Association.

Oleś, P.K. (2008). O różnych rodzajach tożsamości oraz ich stałości i zmianie [Different types of identity]. In P.K. Oleś \& A. Batory (Eds.), Tożsamość i jej przemiany a kultura [Identity and its changes and culture] (pp. 41-84). Warszawa, Lublin: I Wydział Nauk Spolecznych PAN, Wydawnictwo KUL.

Pollard, R. (2008). Dialogue and desire. Mikhail Bakhtin and the linguistic turn in psychotherapy. London: Karnac Books Ltd.

Raggatt, P.T.F. (2000). Mapping the dialogical self: Towards a rationale and method of assessment. European Fournal of Personality, 14, 65-90.

Roberts, J.S., \& Rosenwald, G.C. (2001). Ever upward and no turning back: Social mobility and identity formation among first-generation college students. In D.P. McAdams, R. Josselson, \& A. Lieblich (Eds.), Turns in the road: Narrative studies of lives in transition (pp. 91-119). Washington, DC: American Psychological Association.

Rowan, J., \& Cooper, M. (Eds.), (1999). The plural self: Multiplicity in everyday life. London: Sage Publications.

Stemplewska-Zakowicz, K., Walecka, J., Gabinska, A., Zalewski, B., \& Suszek, H. (2005). Experiments on positioning, positioning the experiments. In P.K. Oleś, \& H.J.M. Hermans (Eds.), The dialogical self: Theory and research (pp. 183-199). Lublin: Wydawnictwo KUL.

Swann, W.B., Jr. (1987). Identity negotiation: When two roads meet. Fournal of Personality and Social Psychology, 53, 1038-1051. 
Tomkins, S.S. (1987). Script theory. In J. Aronoff, A. I. Rabin, \& R. A. Zucker (Eds.), The emergence of personality (pp. 147-216). New York: Springer.

Van Halen, C.,\& Janssen, J. (2004). The usage of space in dialogical self-construction:

From Dante to cyberspace. Identity: An International fournal of Theory and Research, 4, 389-405.

Vleioras, G. \& Bosma, H.A. (2005). Predicting change in relational identity commitments: Exploration and emotions. Identity: An International fournal of Theory and Research, 5, 35-56.

Worden, J.W. (2009). Grief counseling and grief therapy: A handbook for the mental health practitioner. New York: Springer Publishing.

\section{Appendix}

\section{Instructions and questions used in the investigation}

People go through many changes during their life span. Some changes open new opportunities or chances, others make people lose something very important, some part of their own self. This research concerns changes which have brought about a threat to or loss of part of your identity. Read the following questions carefully, try to find such changes in your life and describe their effects.

Have you gone through an experience in your life that you feel has changed you? What has changed in yourself as a result of this experience?

Did you make some decision and as a result you lost somebody or something very important and you felt that you lost some part of yourself?

Have any external circumstances (e.g. change of accommodation) made you feel that you are someone else than before?

When you look at your life, do you notice a period when you felt that you were a different person than before and after it? 


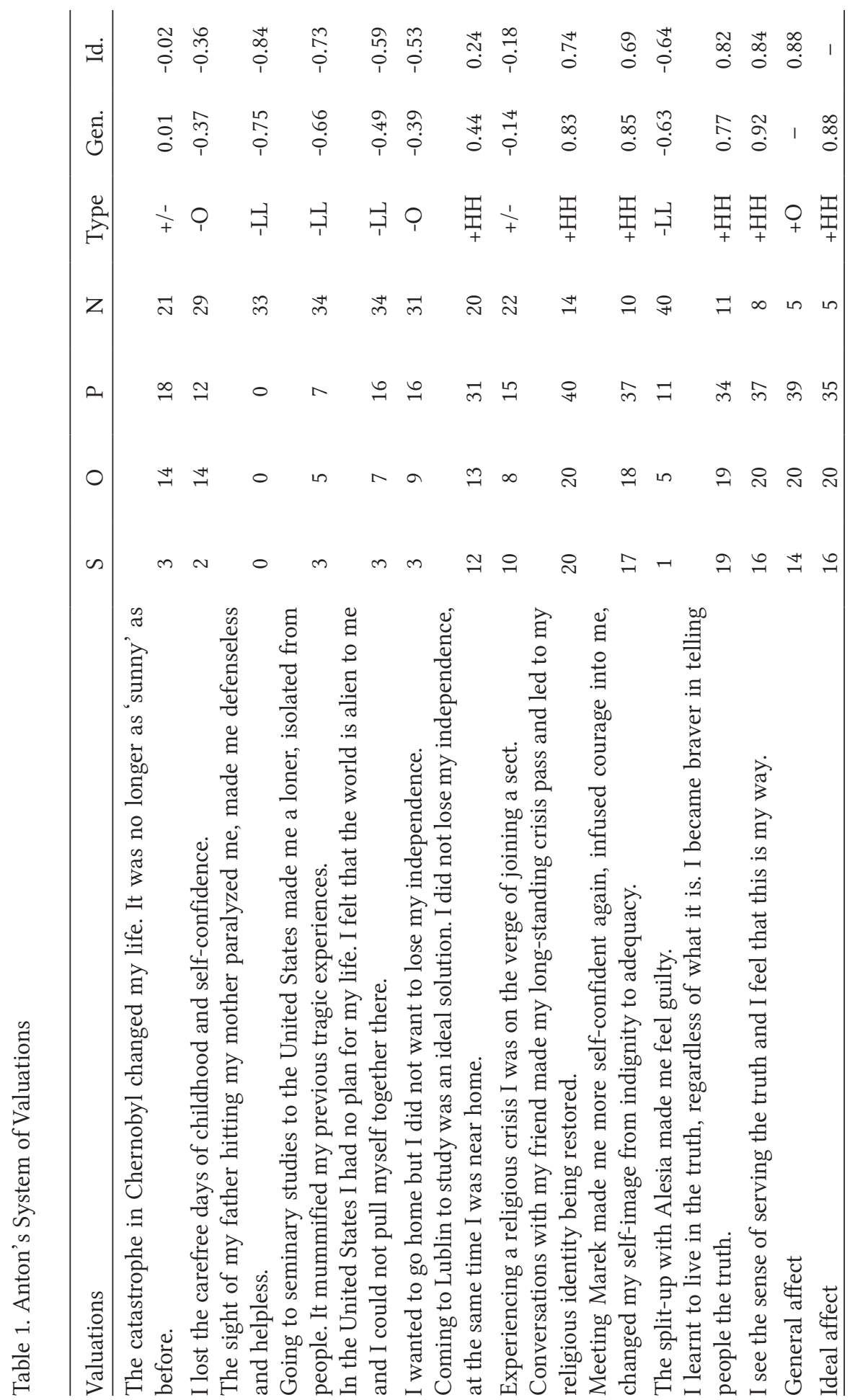




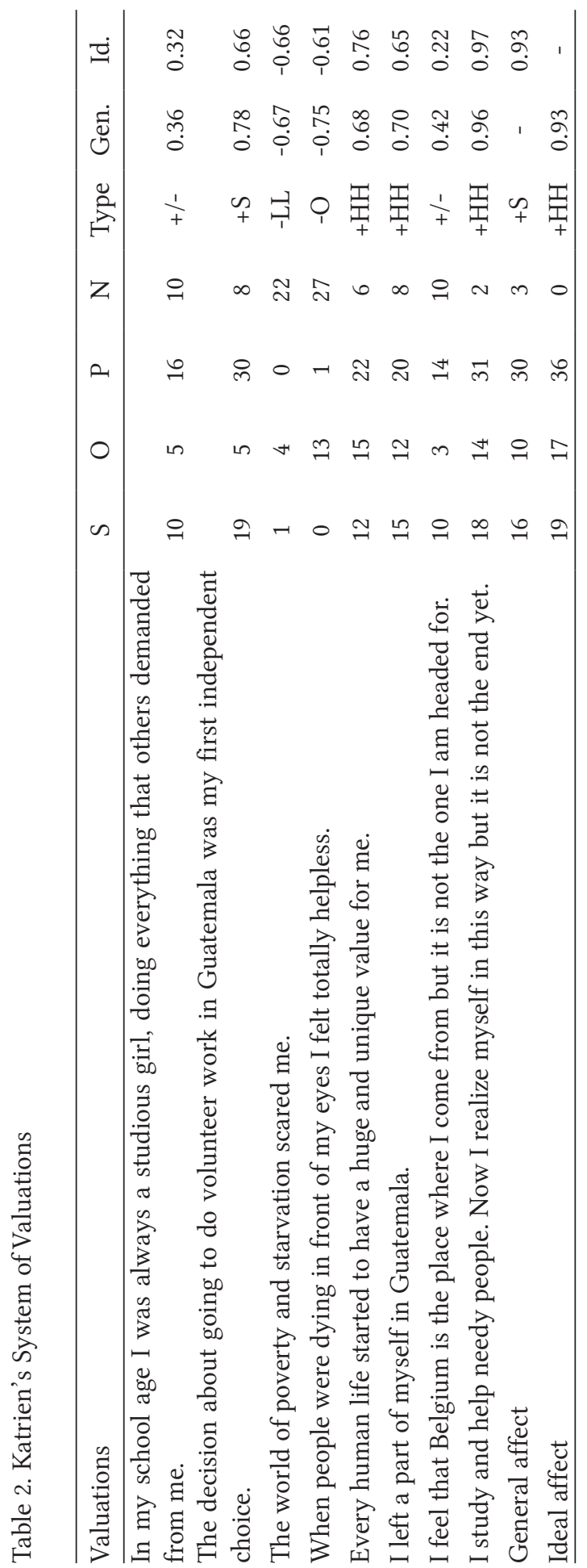




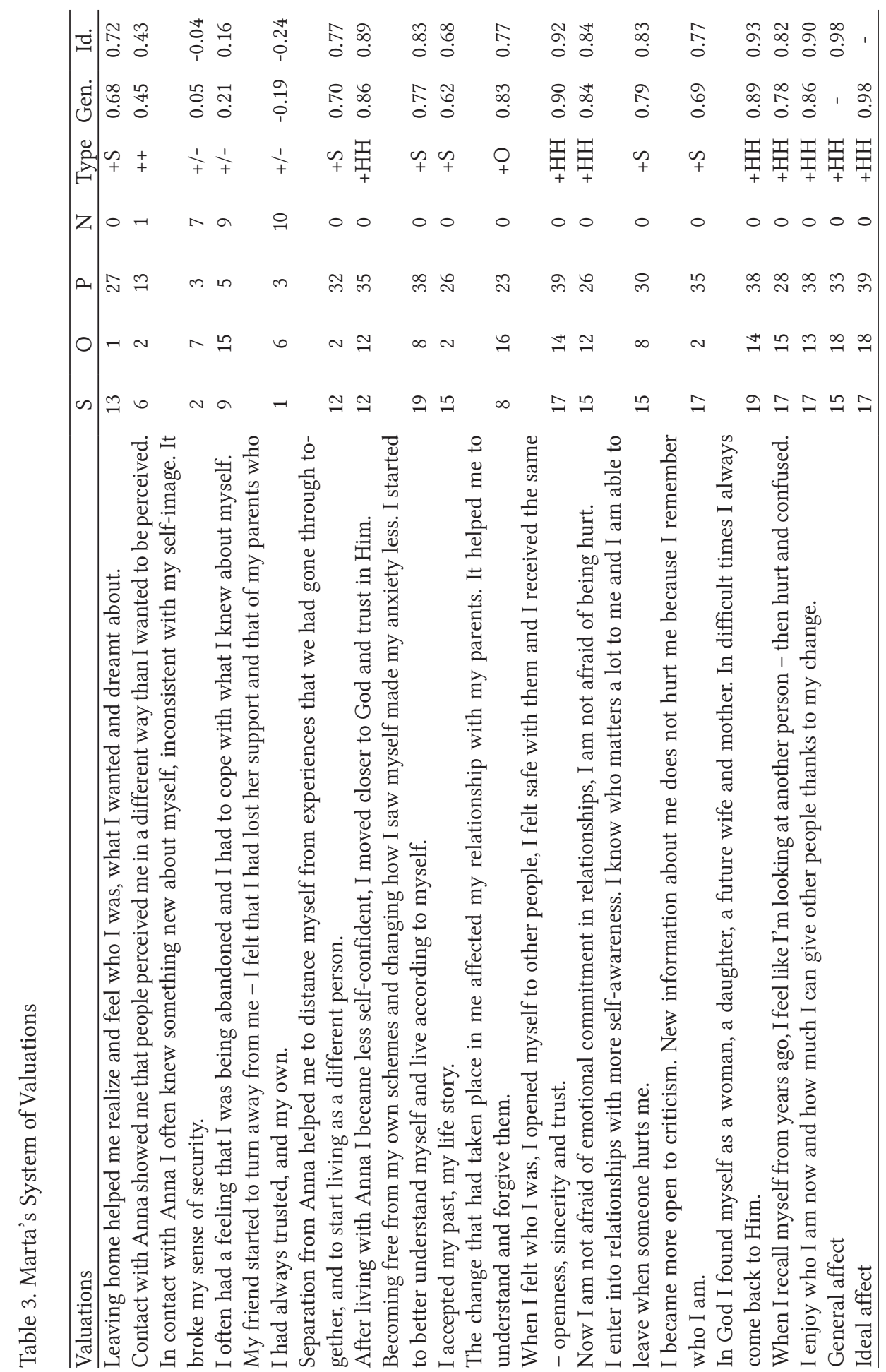




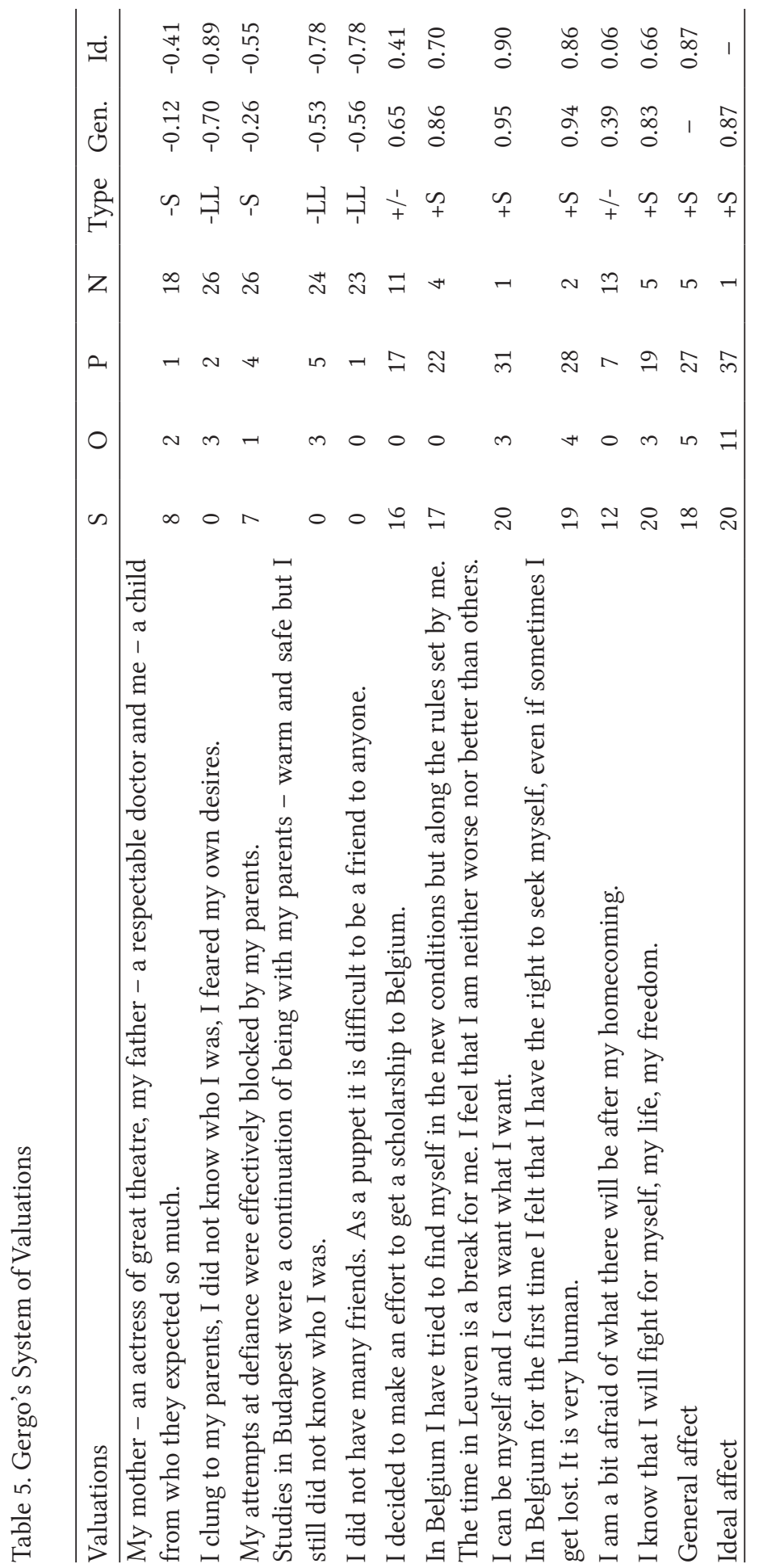




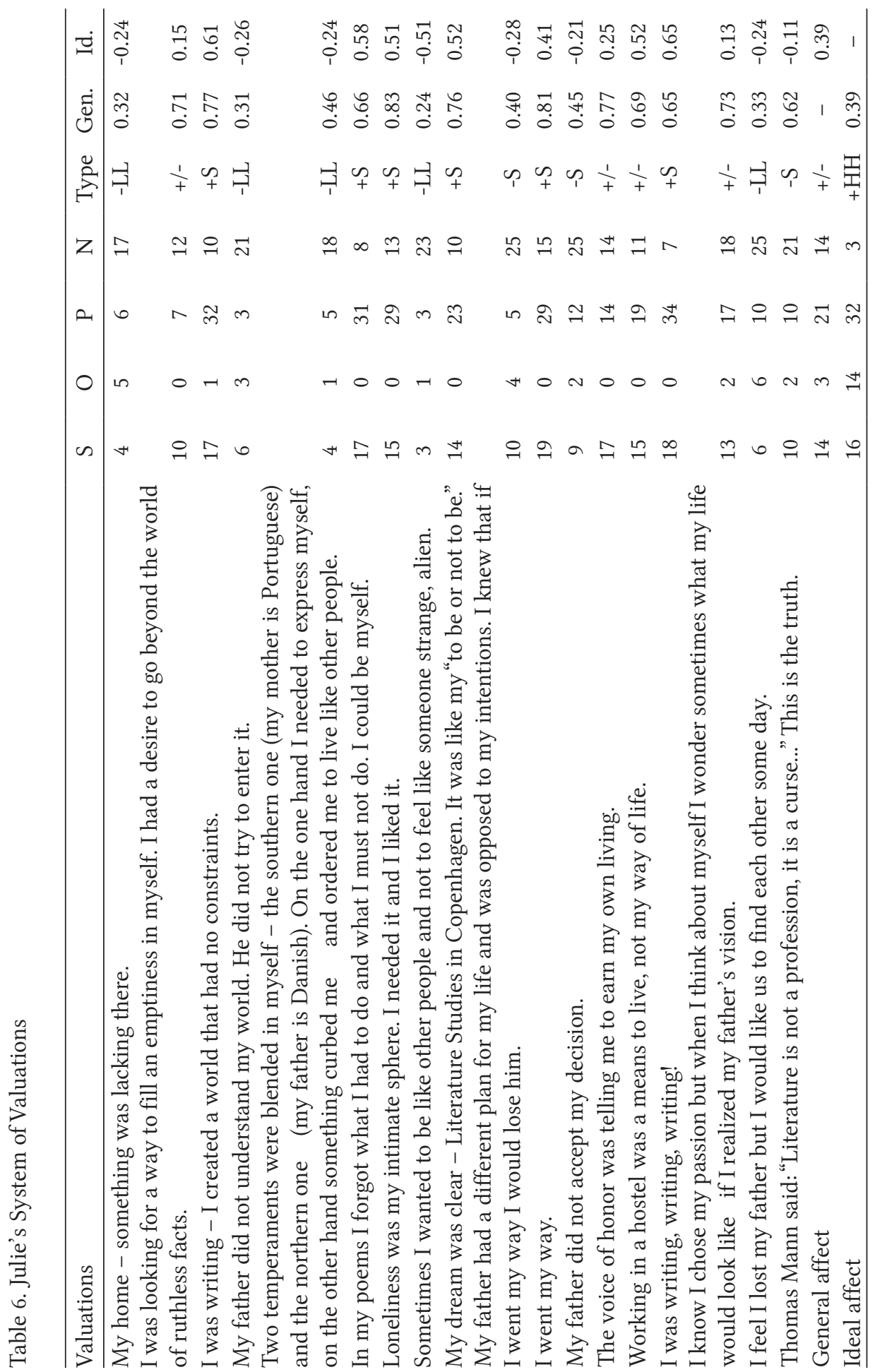

